\title{
Ornamental stone potential areas for land use planning: a case study in a limestone massif from Portugal
}

\author{
Jorge M. F. Carvalho ${ }^{1}$ [ . José Vitor Lisboa ${ }^{1}$
}

Received: 12 October 2017 / Accepted: 24 February 2018

c) Springer-Verlag GmbH Germany, part of Springer Nature 2018

\begin{abstract}
Nowadays, the difficulties of the mining sector in accessing the territory are mostly related to inadequate land use plans. Mineral potential maps have become quite relevant for the land use planning authorities as a decision support tool. This work's goal is to present a methodology based on geological criteria, for the delimitation of potential areas for ornamental stones production in a limestone area of Portugal known as Maciço Calcário Estremenho. This is one of the world's most important regions producing limestone blocks for ornamental purposes. The methodology, applied at a scale similar to the commonly used in land use planning, considers two main geological-based criteria for the definition of potential areas, namely the homogeneity criterion, related to the textural and chromatic homogeneity of the potentially productive lithologic units, and the dimension criterion, which refers to the thickness of the productive unit, to the volume of the deposit and to its spatial layout. Based on the criteria, two main types of potential areas for ornamental stones' production were delimited: specific areas, where the lithostratigraphic units demonstrate ornamental suitability at a very local scale due to highly appreciated particular features, and areas corresponding to the entire outcrop area of some of the lithostratigraphic units, which due to the resource volume are the most relevant potential areas.
\end{abstract}

Keywords Ornamental stones $\cdot$ Mineral potential maps $\cdot$ Land use planning $\cdot$ Maciço Calcário Estremenho $\cdot$ Portugal

\section{Introduction}

In the last decades in Europe, the mining sector was penalized by the constraints that hinder its accessibility to the territory when competing with other possible land uses. These constraints still exist and result from land use plans and policies, which, by obliterating the fact that mineral resources can only be exploited where they occur and by not considering them equally as all other resources, do not promote spaces for their safeguard. This puts at risk the supply of raw materials for the future generations. Some studies

This article is part of a Topical Collection in Environmental Earth Sciences on "Stone in the Architectural Heritage: from quarry to monuments - environment, exploitation, properties and durability", Guest edited by Siegfried Siegesmund, Luís Sousa, and Rubén Alfonso López-Doncel.

Jorge M. F. Carvalho

jorge.carvalho@lneg.pt

1 LNEG - Laboratório Nacional de Energia e Geologia, Estrada da Portela, Bairro do Zambujal, 2610-999 Amadora, Portugal addressed this issue at the turn of the century (Regueiro et al. 2000; Wellmer and Becker-Platen 2002; Christmann 2004; Christmann et al. 2007) and the European Commission (through the Raw Materials Initiative) formally recognized its importance and the need to take actions to solve it (European Commission 2008, 2012). Geologically informed land use planning is the tool for the safeguard of existent or potential mineral deposits.

In Portugal, the sustainable use of geological resources is one of the strategic objectives presented in the National Program of Land Use Policy (Law no. 58, Assembleia da República 2007), which is the code where the main strategic guidelines for the Portuguese territorial development model are established. In turn, the Base Law for the Policy of Soils of land use planning and of Urbanism (Law no. 31, Assembleia da República 2014) establishes the safeguard of places with potential for the exploitation of geological resources as one of the territorial management objectives. Accordingly, the Portuguese normative for land use planning (Decree-Law no. 80, MAOTE 2015) establishes that national territorial development strategies are effectively implemented by municipal land use plans and these shall 